Reprod. Nutr. Dévelop., 1983, 23 (3), 599-606.

\title{
Compatibility and nutritional dependence of mouse egg cylinder fragments associated with amphibian embryonic tissues
}

\author{
F. D. BARBIERI, N. CASTRO, D. C. MICELI
}

Departamento de Biología del Desarrollo, Instituto superior de Investigaciones biológicas,

Consejo nacional de Investigaciones científicas y técnicas and Universidad nacional de Tucumán, Chacabuco 461, 4000 San Miguel de Tucumán, Argentina.

Summary. Embryonic and extraembryonic fragments of mouse egg cylinders at the early primitive-streak stage have been apposed to early gastrula cells of the toad, Bufo arenarum, using two techniques. One lot of fragments was implanted into the blastocoel ; the second lot was cultured in vitro in association with undetermined epiblast excised from the ventral half of the blastocoel roof. All samples were cultured up to 3 days in Barth's solution, optimized for the amphibian embryo and not permitting isolated mouse egg cylinder fragments to survive.

Small grafts, completely surrounded by Bufo cells, had an apparently normal aspect and frequent mitotic figures. Large grafts, attached to the host embryo, were in close contact with the endoblast and mesoblast cells, but the ectoblast layer showed no tendency to cover the egg cylinder fragment. No differentiation was detected in mouse embryo fragments, probably because their development was retarded. The cells in the most proximal region of these fragments, i.e. near the host tissues, had a normal aspect and showed proliferative activity. On the other hand, cells in the most distal region were in advanced involution. The presence of the graft did not appear to impair normal differentiation of the host cells.

\section{Introduction.}

There is much evidence indicating that graft exchanges between embryos of different vertebrate species are viable throughout most of the embryonic period. These combinations have been widely used as a valuable experimental approach to the analysis of early development (see Ebert, 1959 ; Owen, 1959). Transplantations between anuran and urodelean species and grafts of mammalian tissues in the chick embryo showed no incompatibility (see Ebert, 1959). Similar results were obtained when assaying the association of embryonic organs from the chick and the mouse in vitro (Wolff, 1954). There is general consensus that the host does not destroy the graft because it lacks immunological reactivity during 
early development. However, since it is known that cell surface components play an important role in morphogenesis and differentiation, the apparent lack of specificity with which cells of different species adhere to each other is striking. This has been tentatively explained by assuming that some determinants persist on the cell surface of different species during the course of evolution. On the basis of this hypothesis, the viability of the chick-mouse combination might be understood as additional evidence of the evolution of these species from a reptilian stem (Burdick and Steinberg, 1969). The attachment between the xenogeneic embryo fragments has also been tentatively ascribed to the structural similarities of protein molecules throughout the zoological scale (Wolff, 1954; Garrod and Nicol, 1981).

In the present investigation, fragments of mouse and toad embryos were associated in order to determine (a) whether the apposed embryonic fragments of vertebrates not linked by a common ancestry, as amphibians and mammals, would attach to one another, and (b) whether the cells of the quasi cleidoic amphibian embryo (which only requires water and oxygen from the environment) could fulfill the nutritional requirements of the mammalian embryo which receives its nutritional supply from the maternal organism.

\section{Material and methods.}

Embryos. - Female Swiss mice were mated overnight, and the day on which the vaginal plug was found was designated as day 0 . Embryos in the early primitive-streak stage (6-7 days old) (Witschi stages 11-12, according to New, 1966) were isolated from pregnant uteri and put in sterile Tyrode's solution.

The toad, Bufo arenarum, was induced to ovulate by an injection of a pituitary suspension. The oocytes were removed from the ovisacs and inseminated with a sperm suspension prepared by mincing testes in $10 \%$ amphibian Ringer solution. The eggs were allowed to develop in the same saline to the required stage.

Dissection. - Mouse and toad embryos were operated with tungsten needles and hair loops.

After the jelly coats of the amphibian embryo had been dissolved with a $1 \%$ thioglycolic acid solution neutralized with $\mathrm{NaOH}$, the fertilization membrane was removed with sharpened forceps. The mouse embryos were dissected in a Petri dish containing sterile Tyrode's solution. In some experiments, $0.1 \%$ of albumin was added to the medium to make the eggs less sticky and thus facilitate manipulation during dissection. After Reichert's membrane was removed, the egg cylinders were cut transversely at the junction of the embryonic and extraembryonic parts. Fragments of different sizes (about 20-200 $\mu \mathrm{m}$ ) were then arbitrarily cut from the embryonic and extraembryonic regions and either (a) implanted into the blastocoel of late blastulae or early gastrulae of Bufo (stages 9-10, according to Del Conte and Sirlin, 1951) or (b) associated with the epiblast isolated from the ventral side of the blastocoel roof, according to the 
sandwich procedure of Holtfreter (1933). The recipient embryos were about $1.5 \mathrm{~mm}$ in diameter and the epiblast pieces were about $0.5 \times 0.5 \mathrm{~mm}$ square. Operations were carried out in Barth's solution (Barth and Barth, 1959) containing $50 \mu \mathrm{g} / \mathrm{ml}$ of penicillin and $30 \mu \mathrm{g} / \mathrm{ml}$ of dihydrostreptomycin.

Embryo culture and histology. - Grafted amphibian embryos and explants were cultured up to 3 days at $25-27{ }^{\circ} \mathrm{C}$ in Barth's solution containing the antibiotics indicated above. At the end of culture, all material was fixed in Smith's solution and the serial sections were stained with hematoxylin and eosin.

\section{Results.}

As the aim of the present work was to investigate the adhesiveness between mouse and toad embryonic cells as well as the ability of the amphibian embryos to support the development of mouse embryo fragments, the experiments were carried out according to the following design. As stated in Material and methods, the culture conditions were optimized for the amphibian embryo, not the mammalian embryo and most of the mouse embryo fragments were cut large in order to prevent them from passively attaching as a result of being covered by the proliferating tissues of the host embryo or the associated epiblast.

As expected, mouse embryo fragments did not survive when isolated in Barth's solution. In fact, the cells of these specimens exhibited intense cytoplasmic eosinophilia and vacuolization, and their nuclei were pycnotic (fig. 1). The more superficial cells were also found to dissociate to some extent and to remain stuck by a mucous material.

Transplantation experiments. - We performed 71 grafts in seven series of experiments, each conducted with embryos derived from different animals. We found that the cells of Bufo embryos could support the development of mouse embryo fragments during the 3 days of the study, as shown by gross and microscopic observations of the implanted specimens. About $10 \%$ of the grafts remained closely attached to the host, although they were just apposed to the amphibian tissues (fig. 3).

The small specimens of mouse embryo that were completely enveloped by toad tissues remained healthy; they were indistinguishable from normal egg cylinders fixed in utero, and mitotic figures were always present. Further evidence that the host tissues were supporting was provided by the aspect of the grafts partially exposed to the surrounding medium. In fact, while the proximal zone of these grafts had a normal aspect, clear signs of degeneration were present in their most distal portions (figs. 2, 3).

Twenty-four hours after the operation, toad embryos implanted with a piece of egg cylinder were at the closed neural tube stage (stage 16). The wounds were still open because of the large size of the grafts, but no sign of cytolysis was found. When the toad embryos reached the stage of muscular response after 3 days (stage 18), the wounds were much more reduced but not completely closed because the grafts were still attached to the host. They had a normal appearance under the stereomicroscope both before and after fixation. 

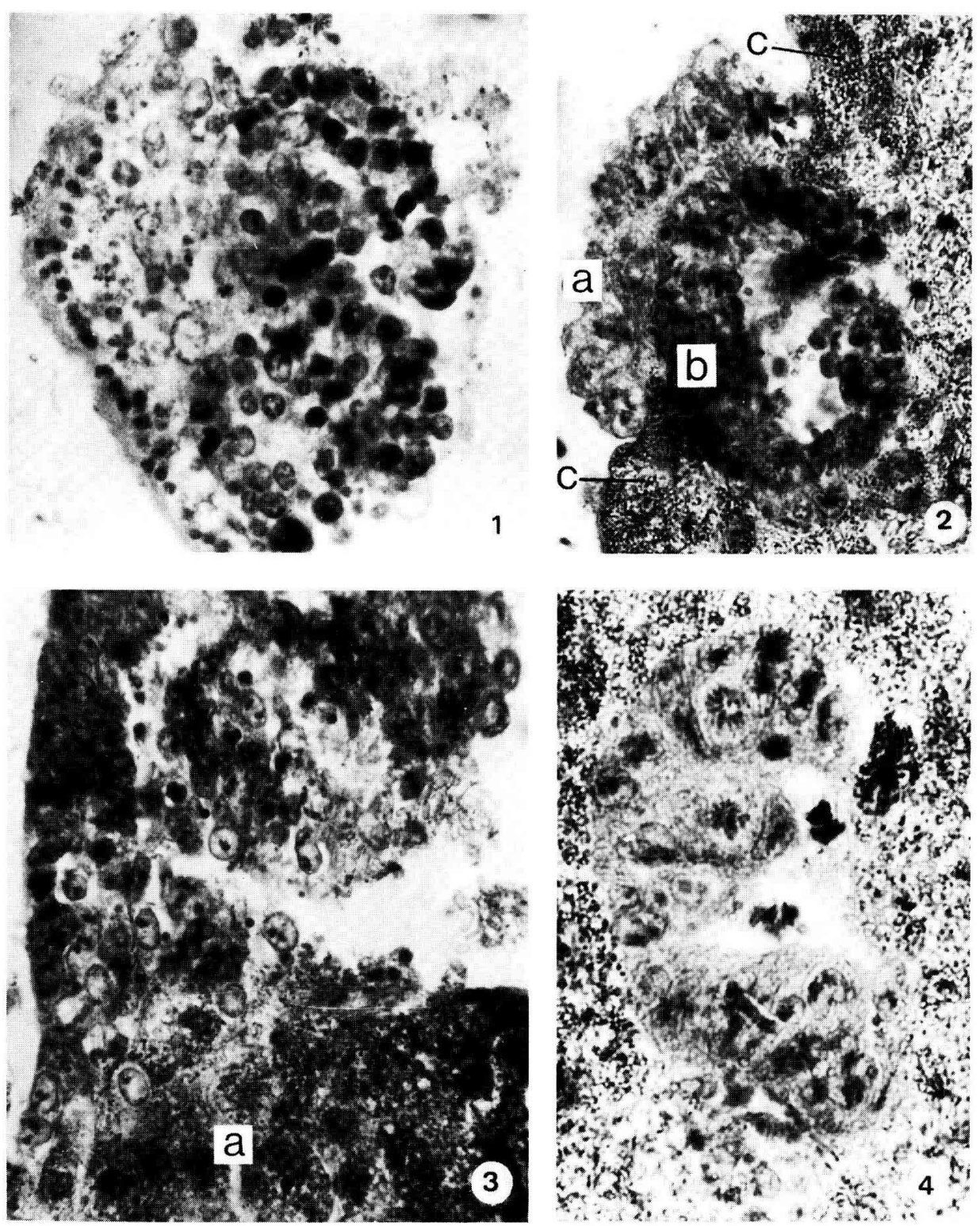
No alteration in host morphology was seen in the histological sections, except for the mechanical disturbance produced by the presence of the implant. In sectioned material, grafts from the embryonic portion of the egg cylinders appeared as compact cell masses or as structures composed of one or two layers of epithelial cells. Because of the atypical disposition of these grafts, it was generally very difficult to relate their morphology to normal embryonic structures. We only recognized the embryonic ectoblast, primitive streak and head process in the most favorable cases. Mitotic figures were often observed.

Extraembryonic structures implanted into the blastocoel developed as cell masses or vesicles lined with epithelial cells that sometimes contained degenerating cells (fig. 2).

In most of the implants, mouse embryonic cells appeared in close contact with the endoblastic and mesoblastic layers of the amphibian embryo (figs. 2, 3). When the apposed surface of the graft was irregularly shaped, the amphibian cells were so close to the graft that there was no open space. Even the voluminous yolk cells of the host were often found to adapt their shape to relatively small anfractuosities on the graft surface. Grafts were also seen associated with the host mesoblast but not with the ectoblast. In no case did the ectoblast cover the implanted egg cylinder fragment. As a general feature, the margins of the wound stopped growing after making contact with the implanted piece (fig. 2). There was no case in which cells were arranged in such a way as to suggest infiltrative growth.

In vitro culture experiments. - Twenty-six explants were performed with mouse and toad embryos obtained from four different animals. The survival of large egg cylinder fragments cultured in combination with toad epiblast was significantly lower than that obtained after implantation of similar fragments into the blastocoel.

Gross observation showed a wide range of variation in the degree of association between graft and host tissue as a function of their relative size. On the one hand, the amphibian epiblast of " sandwiches » enclosing a large egg cylinder fragment showed no tendency to extend over the protruding portion of the fragment, as observed in the preceding series of experiments. On the other hand, the smallest fragments, completely enveloped by the toad epiblast, were in

FIG. 1. - Embryonic portion of an egg cylinder fragment cultured for 48 hrs in Barth's solution $(\times 500)$.

FIG. 2. - Implant of the extraembryonic region of an egg cylinder.

Note that the region of the graft surrounded by endoblastic toad cells (b) appears much less damaged than that emerging from the surface of the host embryo (a). (c : toad ectoblastic cells) $(\times 500)$.

FIG. 3. - A large egg cylinder fragment that remained firm/y attached for the 3 days to the mesoblastic cells of the host (a) by a relatively small area of ectoblast $(\times 500)$.

FIG. 4. - Detail of a very small extraembryonic mouse egg fragment cultured for two days in combination with toad gastrula epiblast.

Mitotic figures are visible. The amphibian cells surrounding the graft are recognized by their high yolk content $(\times 700)$. 
close contact with cells forming the central mass of the explant but not with the more superficial pigmented cells (fig. 4).

Bufo cells contacting mouse cells in the explants exhibited no difference compared to those located far away from the mouse embryo fragment or to those of control epiblast pieces cultured without the associated egg cylinder fragment ; they formed an atypical compact, unorganized tissue covered by ciliated and interspersed secretory cells and melanoblasts.

\section{Discussion.}

The results of implanting fragments of mouse egg cylinders at the early primitive-streak stage to early gastrulae of the toad, Bufo arenarum, or of associating them with an explant of undetermined epiblast of the same species, show that there was no apparent incompatibility for at least 3 days after the operation. No evidence of direct damage to the graft by toxic substances was found, as reported for embryonic grafts between anurans and urodeles (Eakin and Harris, 1945). Furthermore, the grafts attached to the amphibian host with apparently very close cell-cell adhesion. The low percentage of large grafts that attached is probably the result of mechanical problems arising before the cells of the host and the graft adhered. It is possible that the cells formed junctions, as suggested by the fact that, when combined, cells of chick corneal epithelium and mouse epidermis were found to make stable desmosomes (Overton, 1977).

In this first assay of embryonic cell adhesion between a cold and a warmblooded species, we decided that, in order to minimize alterations of the cell surface structure, it was preferable to test the association of embryo fragments rather than the aggregation of dissociated cells. As a matter of fact, we still do not know to what extent the artifactual alteration of cell surface molecules during the dissociation process may account for the different results on various mouse-chick combinations. Thus, while several cell associations seemed to indicate that there is no sorting-out according to species origin (Moscona, 1957, 1960, 1961, 1962 ; Garber and Moscona, 1964 ; Garber et al., 1968 ; Burdick, 1972), this conclusion has been questioned by later experiments (Burdick and Steinberg, 1969) ; even sorting-out followed by cell intermixing has been reported for combinations of mouse and chick limb mesoblast (Burdick, 1970). It has been generally concluded that selective adhesive behavior is probably less influenced by species difference than by tissue difference (Garrod and Nicol, 1981).

Despite the intimate contact established between mouse and toad cells, no propensity to infiltrative growth was noted. This contrasts with the association in vitro of embryonic organs of mouse and chick carried out by Wolff (1954); the limits of this association tended to disappear due to the migration of connective cells into the alien tissues and the formation of chimeric epithelial structures.

The present study also suggests that, in addition to cell compatibility, the mammalian embryo fragments seemed to be nutritionally dependent on the amphibian embryonic cells. This was inferred from the fact that the aspect of the 
cells of fragments held in amphibian saline without a serum component appeared to be normal, as they remained attached to the host embryonic tissues and, in particular, as the large fragments seemed to be normal only in the vicinity of toad cells. In the light of this assumption, the presence of mitotic figures might be interpreted as an expression of proliferative activity, although the present results do not exclude the possibility that these figures could represent a process initiated prior to grafting that remained in an arrested state during the experiments. It is obvious that some nutrients must have been released from the host cells; otherwise, the mouse embryonic cells could not have multiplied in a serum-free hypothonic saline medium (see New, 1966, 1978 ; Skreb and Svajger, 1973 ; Hsu, 1979).

The lack of apparent differentiation in the sectioned material may be ascribed to a slower rate of graft development. It should be noted in this respect that there is a delay in mouse embryonic development, even when the embryos are transplanted to extrauterine sites of the same species (Fawcett et al., 1947), and that the specimens of the present experiments were kept at room temperature. On the other hand, the cells of the host embryo were found to differentiate normally without any apreciable reaction.

Reçu en août 7982.

Accepté en janvier 1983.

Acknowledgements. - We wish to thank Mr. Roberto Ordonez and Dr. Raymond F. Laurent for their assistance in preparing this paper, Mr. José Greco and Mr. Enrique Dozetos for technical assistance and Mr. Hugo Gomez for typing the text. F.D.B. and D.C.M. are members of the Career Investigator of the CONICET, and N.C. was a CONICET fellow while this work was carried out.

Résumé. Compatibilité et dépendance nutritionnelle de fragments de cylindre de l'œuf de Souris associés à des tissus embryonnaires d'Amphibien.

Des fragments embryonnaires et extraembryonnaires du cylindre d'œuf de souris au stade de la lignée primitive ont été associés avec des cellules de la jeune gastrula de Bufo arenarum suivant deux procédés différents. Une série a été implantée dans le blastocele. Une seconde série a été cultivée in vitro en combinaison avec de l'épiblaste indéterminé prélevé du côté ventral du toit du blastocèle. Tous les échantillons ont été cultivés pendant trois jours dans la solution de Barth, optimisée pour l'embryon d'amphibien, et ne permettant pas la survie des fragments isolés de l'œuf de souris. Les greffons de petite taille se présentaient entièrement entourés par les cellules de Bufo, avec un aspect apparemment normal et de fréquentes figures mitotiques. Les greffons de grande taille étaient bien fixés a l'hôte en contact intime avec ses cellules endoblastiques et mésoblastiques. D'autre part, le feuillet ectoblastique de l'embryon d'amphibien n'a montré aucune tendance à couvrir le fragment du cylindre ouf. Les fragments d'embryon de souris ne montraient pas de différenciation probablement à cause d'un retard dans leur développement. Les cellules localisées dans la région proximale du greffon, proche des tissus de l'hôte, avaient une structure d'apparence normale et présentaient des mitoses. Au contraire, les cellules qui se trouvaient dans la région distale montraient un état de régression avancée. La présence du greffon ne semblait pas affecter la différenciation normale des cellules de I'hôte. 


\section{References}

BARTH L. G., BARTH L. J., 1959. Differentiation of cells of the Rana pipiens gastrula in unconditioned medium. J. Embryol. exp. Morph., 7, 210-222.

BURDICK M. L., 1970. Cell sorting-out according to species in aggregates containing mouse and chick embryonic limb mesoblast cells. J. exp. Zool., 75, 357-368.

BURDICK M. L., 1972. Differences in the morphogenetic properties of mouse and chick embryonic liver cells. J. exp. Zool., 180, 117-125.

BURDICK M. L., STEINBERG M. S., 1969. Embryonic cell adhesiveness : Do species differences exist among warm-blooded vertebrates? Proc. nat. Acad. Sci. USA, 63, 1169-1173.

DEL CONTE, E., SIRLIN J. L., 1951. Serie tipo de los primeros estadíos embrionarios en Bufo arenarum. Acta zool. lilloana, 12, 495-499.

EAKIN R. M., HARRIS M., 1945. Incompatibility between amphibian hosts and xenoplastic grafts as related to host age. J. exp. Zool., 98, 35-64.

EBERT J. D., 1959. The acquisition of biological specificity, 619-693. In BRACHET J., MIRSKY A., The cell, Vol. 1. Acad. Press, New York.

FAWCETT D. W., WISLOCKI G. B., WALDO C. M., 1947. The development of mouse ova in the anterior chamber of the eye and in the abdominal cavity. Am. J. Anat., 81, 413-443.

GARBER B. B., MOSCONA A. A., 1964. Aggregation in vivo of dissociated cells. 1. Reconstruction of skin in the choriallantoic membrane from suspensions of embryonic chick and mouse skin cells. J. exp. Zool., 155, 179-202.

GARBER B. B., KOLLAR E. J., MOSCONA A. A., 1968. Aggregation in vivo of dissociated cells. III. Effects of state of differentiation of cells on feather development in hybrid aggregates of embryonic mouse and chick cells. J. exp. Zool., 168, 455-472.

GARROD D. R., NICOL A., 1981. Cell behaviour and molecular mechanisms of cell-cell adhesion. Biol. Rev., 56, 199-240.

HOLTFRETER J., 1933. Der Einfluss von Wirtsalter und Verschiedenen Organbezirken auf die Differenzierung von angelagerten Gastrulaektoderm. W. Roux's Arch. EntwMech. Org., 127, 619775.

HSU Y., 1979. In vitro development of individually cultured whole mouse embryos from blastocyst to early somite stage. Dev. Biol., 68, 453-461.

MOSCONA A. A., 1957. The development in vitro of chimeric aggregates of dissociated embryonic chick and mouse cells. Proc. nat. Acad. Sci. USA, 43, 184-194.

MOSCONA A. A., 1960. Patterns and mechanisms of tissue reconstruction from dissociated cells, 45-70. In RUDNICK D., Developing cell systems and their control. Ronald Press, New York.

MOSCONA A. A., 1961. Rotation-mediated histogenetic aggregation of dissociated cells : a quantifiable approach to cell interactions in vitro. Exp. Cell Res., 22, 455-475.

MOSCONA A. A., 1962. Analysis of cell recombination in experimental synthesis of tissues in vitro. J. cell. comp. Physiol. (suppl. 1) 60, 65-80.

NEW D. A. T., 1966. The culture of vertebrate embryos. Logos Press, London.

NEW D. A. T., 1978. Whole-embryo culture and the study of mammalian embryos during organogenesis. Biol. Rev., 53, 81-122.

OVERTON J., 1977. Formation of junctions and cell sorting in aggregates of chick and mouse cells. Dev. Biol., 55, 103-116.

OWEN R. D., 1959. Genetic aspects of tissue transplantation and tolerance. J. Med. Educ., 34, 366-383.

SKREB N., SVAJGER A., 1973. Histogenetic capacity of rat and mouse embryonic shields cultivated in vitro. $W$. Roux' Arch., 173, 228-234.

WOLFF E., 1954. Potentialités et affinités des tissus, révélées par la culture in vitro d'organes en associations hétérogènes et xénoplastiques. Bull. Soc. Zool. France, 79, 357-368. 